\title{
Preface: Querying the Kabul Hypothesis
}

This book situates nineteenth-century Afghanistan in the context of British Indian colonialism. The general focus is commerce, mainly how local actors including Afghan nomads and Indian bankers responded to state policies regarding popular and lucrative commodities such as fruit and tea. Within those broad commercial concerns, specific attention is given to developments in and between the urban market settings of Kabul, Peshawar, and Qandahar. The colonial political emphasis on Kabul had significant commercial consequences for that city and its economic connections to the two cities it displaced to become the sole capital of the emerging state. The Kabul hypothesis therefore represents a colonial political strategy, and its effects on Kabul-Peshawar and Kabul-Qandahar economic relations are the subject of this book.

There are two basic conclusions to be drawn from the work as a whole. The first runs against standard interpretations of nineteenth-century Afghanistan. In most renditions of this period, Afghanistan remains immune from colonialism emanating from British India due to the outcomes of the two AngloAfghan wars of 1839-42 and 1878-80. The two conflicts are usually interpreted simply as either exceptional "failures" for the British imperial invaders or predictable "victories" for the local Afghan defenders. The basic point made in what follows is that despite the military results of the two wars, Afghanistan is in fact a colonial construct in political, economic, and intellectual terms, at least. However, it will also be made clear that Afghanistan's colonial moorings in British India by no means denied agency to local actors. A secondary conclusion derived from the facts of colonialism's determining influence on Afghanistan is that the development of a relatively strong state in the late nineteenth century signaled the beginning of intensifying market hardships for most Afghans. 


\section{Chronology Overview and Content Summary}

At the state level, there are two principal groups of actors under consideration, namely, British colonial officials and representatives of the Afghan state. The relationship between those two political communities was conditioned by inequalities, ambiguities, and inconsistencies characterizing colonial encounters elsewhere in nineteenth-century India, and beyond. The political relationship between Afghan state officials and British colonial authorities in the $1800 \mathrm{~s}$ evolved through a three-phase chronology of engagement, distancing, and reengagement. The book is correspondingly organized on the basis of "experimental, interim, and routinization" phases that can be outlined as follows.

The experimental period begins in 1809 with the arrival of the first British colonial delegation at the Afghan court. It ends with the annihilation of the first British invasion force in 1842. The initial thirty-three years of British Indian contact with nascent Afghanistan involved a number of commercial experiments that in many ways culminated with the first Anglo-Afghan war. After a swift retribution campaign to account for the "Afghan disaster," the British generally kept political distance from Kabul for another thirty years or so until a second phase of more direct and re-intensified interaction began. The experimental period is richly documented by archival and published sources.

This interim period from the end of the first war in 1842 until the beginning of the second war in 1878 was an active one both locally and globally. This period of intense industrialization involved the large-scale development of railroads, telegraphy, and transoceanic steamship trade and travel that transformed an increasingly international and integrated world economy. Because there was not substantial or sustained contact between Durrani state and British colonial authorities during this interim phase, the period is weakly documented and as such not considered in this work. However, the transformations that occurred in terms of global commerce and the advancement of industrial technology reframed the context in which the second phase of active Anglo-Afghan relations occurred.

The second part of the book considers Abd al-Rahman's reign, for which there is a great deal of archival and published material available. In 1880 the British appointed Abd al-Rahman as the Amir of Kabul to facilitate their evacuation at the end of a second failed occupation, and he ruled until his death in 1901. During this twenty-one-year period, Afghanistan's relationship with British India was routinized in a number of ways. The Abd al-Rahman period is also significant for standardizing state-society relations in Afghanistan. 
The periodization described earlier and detailed later in this work follows military and political calendars associated with the two Anglo-Afghan wars. In terms of content, however, each part of the book considers a different set of economic actors and sectors. After establishing Kabul's roles as a center of production and as a transition market, the first part of the book deals with the commercial contracts around which the British engaged local people to exploit the grounded and mobile resources previously identified. It also considers a larger grand plan for Kabul and its markets in relation to the global economy, and discusses the transformation of local commercial institutions and practices that occurred in the context of the first colonial occupation.

The second part of the book deals with Abd al-Rahman's reign and his relationship to the British by focusing on the cash subsidies he received, and how those resources were part of broader program of reconfiguring Afghanistan's relationship to colonial markets. Abd al-Rahman's agenda of fiscal reorientation toward India, and through it global capitalism, carried significant domestic consequences. In this crucial period, new routines in Afghanistan's dealings with the outer world were established, and new bureaucratic structures and state practices were institutionalized. During Abd al-Rahman's colonially configured reign, Afghanistan assumed its structural position on the periphery of modern global capitalism.

For chronological clarity, a list of Durrani rulers mentioned in this book appears below, although dates of reign for a given dynast can also be found in the text:

Ruler
Ahmad Shah
Timur Shah
Zaman Shah
Shah Shuja
Dost Muhammad
Sher Ali
Muhammad Afzal
Muhammad Azam
Muhammad Yaqub
Abd al-Rahman
Habibullah
Amanullah

Reign

$1747-72$

$1773-93$

1793-1800

1803-9 and 1839-42

$1826-38$ and $1842-63$

1863-66 and 1869-78

1866-67

1867-68

1879

1880-1901

1901-19

1919-29 
This print edition of Connecting Histories in Afghanistan published by Stanford University Press follows the electronic publication of the book by Columbia University Press through the American Historical Association's Gutenberg-e Program. A number of minor corrections and additions to the electronic text have been made for this print version, but an effort was made to keep the electronic and printed version of the text as parallel as possible. The Gutenberg-e version of Connecting Histories is a unique repository for images (http://www. gutenberg-e.org/hanifi/gallery.html), a number of which (the maps, documents and coins) have magnification features not possible to reproduce in print form. 